\title{
Evaluation of Bottom Sediment Qualities in Ihetutu Minefield, Ishiagu, Nigeria
}

\author{
R. Sha'Ato, A. G. Benibo*, A. U. Itodo, R. A. Wuana \\ Department of Chemistry and Centre for Agrochemical Technology \& Environmental Research (CATER), Federal University of \\ Agriculture, Makurdi, Nigeria \\ Email: *ao_benibo@yahoo.com
}

How to cite this paper: Sha'Ato, R., Benibo, A. G., Itodo, A. U., \& Wuana, R. A. (2020). Evaluation of Bottom Sediment Qualities in Ihetutu Minefield, Ishiagu, Nigeria. Journal of Geoscience and Environment Protection, 8, 125-142.

https://doi.org/10.4236/gep.2020.84009

Received: March 13, 2020

Accepted: April 23, 2020

Published: April 26, 2020

Copyright (c) 2020 by author(s) and Scientific Research Publishing Inc. This work is licensed under the Creative Commons Attribution International License (CC BY 4.0).

http://creativecommons.org/licenses/by/4.0/

\begin{abstract}
Bottom sediment qualities in Ihetutu minefield were assessed to ascertain the impact of $\mathrm{Pb}-\mathrm{Zn}$ mining activities on the sediments from streams, rivers and ponds in the area. Levels of $\mathrm{Cu}, \mathrm{Zn}, \mathrm{Fe}, \mathrm{Ni}, \mathrm{Mn}, \mathrm{Pb}, \mathrm{Cd}$ and $\mathrm{Cr}$ and some physico-chemical parameters were measured in bottom sediments taken from four sampling stations (streams/mine pits) within Ihetutu minefield of Ishiagu which receives discharges from mining and human activities, and a control sampling station in Uturu (about $12 \mathrm{~km}$ away from study area). The study was conducted in four seasons (Rainy, Late Rainy, Dry, and Late Dry Seasons). Sample digestion was done with a temperature adjustable block digester. Heavy metal analysis was carried out with Flame atomic absorption spectrophotometer (FAAS) while other physico-chemical parameters were determined with standard field and laboratory procedures. Ranges of mean values of results obtained were; $\mathrm{pH}=5.81-6.44, \mathrm{EC}=269.00-1545.00 \mu \mathrm{S} / \mathrm{cm}, \mathrm{Cl}^{-}=43.30-$ $112.33 \mathrm{mg} / \mathrm{kg}$, alkalinity $=0.70-1.25 \mathrm{mg} / \mathrm{kg}, \mathrm{NO}_{3}^{-}=5.90-7.90 \mathrm{mg} / \mathrm{kg}$, TOC $=0.81-1.75 \mathrm{mg} / \mathrm{kg}, \mathrm{TOM}=1.40-3.02 \mathrm{mg} / \mathrm{kg}, \mathrm{Cu}=4.74-50.93 \mathrm{mg} / \mathrm{kg}, \mathrm{Zn}=$ $26.78-57.07 \mathrm{mg} / \mathrm{kg}, \mathrm{Fe}=1066.19-1764.05 \mathrm{mg} / \mathrm{kg}, \mathrm{Mn}=36.66-42.96$ $\mathrm{mg} / \mathrm{kg}, \mathrm{Ni}=4.02-17.19 \mathrm{mg} / \mathrm{kg}, \mathrm{Pb}=38.01-162.23 \mathrm{mg} / \mathrm{kg}, \mathrm{Cd}=1.01-25.90$ $\mathrm{mg} / \mathrm{kg}$, and $\mathrm{Cr}=1.23-1.62 \mathrm{mg} / \mathrm{kg}$. Assessment of heavy metals pollution, using pollution indices revealed that Contamination factor ranged from moderate to very high degree of contamination while Pollution load index also showed a deterioration of bottom sediment qualities. Geoaccummulation index indicated moderate to very high pollution, especially with $\mathrm{Cu}, \mathrm{Zn}, \mathrm{Pb}$, and $\mathrm{Cd}$ in the mine pit, while Enrichment factor indicated high enrichments and inputs from anthropogenic sources especially, the $\mathrm{Pb}-\mathrm{Zn}$ mining activities. Pollution of the area by heavy metals was in the order of $\mathrm{Fe}>\mathrm{Pb}>\mathrm{Zn}>$ $\mathrm{Mn}>\mathrm{Cu}>\mathrm{Ni}>\mathrm{Cd}>\mathrm{Cr}$. Highest positive correlation $(\mathrm{r}=0.992)$ was between $\mathrm{Pb}$ and $\mathrm{Cu}$ while the highest negative correlation $(\mathrm{r}=-0.789)$ was between $\mathrm{Ni}$ and Mn. Analysis of variance (ANOVA) at significance level, $\alpha=$
\end{abstract}


0.05 , showed no statistically significant differences in the sampling stations $(p>0.05)$. Compared to background (control), DPR and other standard guidelines/values, bottom sediments from Ihetutu minefield were highly polluted with $\mathrm{Pb}, \mathrm{Zn}$ and $\mathrm{Cu}$ especially at the mine site. The overall results from the study revealed that toxic substances released from the prolonged $\mathrm{Pb}-\mathrm{Zn}$ mining activities in the study area have impacted negatively on the bottom sediments, thereby also possibly deteriorating the quality of lives of the bottom sediments dwelling organisms in the streams, rivers, and pits/ponds in the area.

\section{Keywords}

Anthropogenic, Enrichment, Mining, Pollution, Sediment

\section{Introduction}

Mining is a huge economic resource at Ihetutu, Ishiagu, Nigeria. The Ihetutu $\mathrm{Pb}-\mathrm{Zn}$ mine in Ishiagu is the oldest (Elom, 2018), amongst the several mines dotting the area. Despite the huge benefits accruing from the mining business to the government, individuals, and corporate bodies engaged in it, its activities constitute the most important source of heavy metals in the environment. It is a business that seriously destroys the environment, with the large volumes of wastewater, drainage wastes and tailings, generated through its activities; and spoils the landscape and the surrounding environment with inorganic pollutants, particularly heavy metals. According to Zhang et al. (2011), lead/zinc mining and smelting activities are some of the primary sources of heavy metals pollution in the environment.

Heavy metal pollution is intensified when mining exposes metal bearing ores, more than they are exposed through the gradual and natural process of weathering or erosion. Intensification of heavy metal pollution, occurs when mining is carried out in a crude manner and associated wastes are untreated and improperly dumped or discharged (Nwaugo et al., 2007). Heavy metals have serious ecological effect as a result of their toxicity and their accumulation in both sediment and biota because they are not biodegradable and undergo a global ecological cycle (Ahmadipour et al., 2014).

The predominant mode of mining in Ihetutu, is the open cast which involves ripping the ground open to unearth the precious substances in it. Adverse environmental consequences of open pit mining include sediment and water qualities degradation due to destruction of vegetation, exposure of the soil to surface run-offs, as well as dumps that have been confirmed to accommodate harmful minerals and chemicals that contaminate the soil, plant, water and air quality (Osuocha et al., 2015).

Heavy metal discharged into the environment rapidly combines with particulates and settles in bottom sediments of water bodies either by direct discharge 
or surface run-offs (Inengite et al., 2010). The accumulation of metals from the overlying water to the sediment depends on several external environmental factors including $\mathrm{pH}$, conductivity and the available surface area for adsorption caused by the variation in particle size distribution. It was suspected that the environment within the study area must have been completely polluted by wastes from the mining processes and through the introduction of heavy metals into surface water bodies and bottom sediments thus becoming a source of contamination and threat to aquatic biota. These environmental concerns therefore made this study imperative.

The objective of this paper is thus to evaluate the qualities of the bottom sediments from streams, rivers, and ponds in Ihetutu mining areas of Ishiagu, by assessing the levels of contamination by toxic substances including heavy metals and other physico-chemical species released to the environment from the $\mathrm{Pb}-\mathrm{Zn}$ mining operations, Data obtained from the study will be compared with control (background/pre-mining) and standard guideline values including Department of Petroleum Resources (DPR), and other international standards.

This study would help to identify and quantify pollutants especially heavy metals mostly from the prolonged $\mathrm{Pb}-\mathrm{Zn}$ mining operations, and their impact on bottom sediment qualities in Ihetutu mining areas. It would provide information on the actual state of bottom sediments in the area; and data that would enhance policies on mine waste management and remediation operations on bottom sediments, and also useful for impact assessment activities in the study area.

\section{Materials and Methods}

\subsection{The Study Area}

The Ihetutu minefield is located in Ishiagu, Nigeria, and falls within latitudes $\mathrm{N}$ $5^{\circ} 51 /$ and $\mathrm{N} 5^{\circ} 59 /$ and longitudes $\mathrm{E} 7^{\circ} 24 /$ and $\mathrm{E} 7^{\circ} 40 /$. Lead-zinc and hard rock (aggregate) mining has been ongoing in the area since the 1950s. The Ishiagu area covers an expanse of about $450 \mathrm{~km}^{2}$ and supports an estimated population of over two hundred and fifty thousand persons (IMWT, 1984; Ezekwe, 2009). The area is accessible through the Enugu-Port Harcourt Railway line which runs North-South through the centre of the study area; the Enugu-Port Harcourt oil pipe line which runs north east-south west; the Enugu-Port Harcourt Express Road which passes through the extreme north western corner of the study area; the Lekwesi-Obiagu Road which runs east-west in the northern part of the study area and the Okigwe-Afikpo Road which runs East-Northeast-East in the southernmost part of the study area.

\subsection{Sample Collection}

Sampling was done in four seasons; Rainy Season (RNS), Late Rainy Season (LRS), Dry Season (DRS), and Late Dry Season (LDS) between 2018 and 2019 (Table 1). Bottom sediments were collected from depths of $60 \mathrm{~cm}$ below the water surface 
Table 1. Sampling Field data summary.

\begin{tabular}{|c|c|c|c|c|}
\hline Sampling Stations & Sampling Seasons & Station locations & Latitude & Longitude \\
\hline CBS1 (control station) & RNS; LRS; DRS; LDS & Aku Stream, near Masters Energy, Uturu. & N $5^{\circ} 51^{\prime} 34^{\prime \prime}$ & E $7^{\circ} 31^{\prime} 13^{\prime \prime}$ \\
\hline SBS3 & RNS; LRS; DRS; LDS & Lead-Zinc Mine Pit, Ihetutu. & N 551'35" & $\mathrm{E} 7^{\circ} 31^{\prime} 13^{\prime \prime}$ \\
\hline SBS6 & RNS; LRS; DRS; LDS & Lead-zinc mine downstream/run-off, Ihetutu. & $\mathrm{N} 5^{\circ} 55^{\prime} 50^{\prime \prime}$ & E 7²9'1" \\
\hline SBS7 & RNS; LRS; DRS; LDS & NNPC pipeline Stream, Ihetutu. & $\mathrm{N} 5^{\circ} 56^{\prime} 5^{\prime \prime}$ & E $7^{\circ} 31^{\prime} 6^{\prime \prime}$ \\
\hline SBS8 & RNS; LRS; DRS; LDS & Iyiogwe stream, Ihetutu. & N $5^{\circ} 56^{\prime} 53^{\prime \prime}$ & $\mathrm{E} 7^{\circ} 32^{\prime} 35^{\prime \prime}$ \\
\hline
\end{tabular}

RNS = Rainy Season $\left(12^{\text {th }}\right.$ May, 2018); LRS = Late Rainy Season $\left(1^{\text {st }}\right.$ October, 2018); DRS $=$ Dry Season $\left(1^{\text {st }}\right.$ December, 2018$)$; LDS $=$ Late Dry Season $\left(12^{\text {th }}\right.$ April, 2019).

in the streams and pits at designated points. The samples were scooped directly from the bottom of the pit/stream at a depth of $1-3 \mathrm{~cm}$ (Kasich et al., 2012), with the aid of stainless steel scoopinto pre-cleaned plastic sampling bags (IAEA, 2003). Three bottom sediment subsamples were taken randomly from each riv$\mathrm{er} / \mathrm{stream} / \mathrm{pit}$ and mixed to form composite samples of about $1.0 \mathrm{~kg}$ for the sampling station. Collected samples were stored in an ice box at about $4{ }^{\circ} \mathrm{C}$, and later transferred to the laboratory for processing and analysis.

\subsection{Sample Digestion and Analysis}

Samples were first air-dried, grounded to fine particles, passed through a $2 \mathrm{~mm}$-sieve and homogenized (Radulescu et al., 2014). $5 \mathrm{~g}$ of the homogenized sample was weighed into a $100 \mathrm{ml}$ glass beaker, and a mixture of $2 \mathrm{~mL}$ of $\mathrm{HNO}_{3}, 6 \mathrm{~mL}$ of $\mathrm{HCl}$ and $20 \mathrm{~mL}$ of distilled water was added to it. The mixture was heated on a heating mantle of a temperature-adjustable block digester, and allowed to digest to about $5 \mathrm{~mL}$. The digested sample was allowed to cool and then filtered into 50 $\mathrm{mL}$ volumetric flask using a filter paper (Whatman No. 42). The filtrate was diluted to $50 \mathrm{~mL}$ with distilled water. Heavy metal concentrations in the samples were determined using a Flame Atomic Absorption Spectrophotometer (FAAS), in accordance with ASTM D1971/4691 (2016).

\subsection{Analysis of Physico-Chemical Parameters}

$\mathrm{pH}$ of the bottom sediments was determined using a $\mathrm{pH}$ meter. The meter was calibrated over the appropriate range using buffer 4 and buffer 7 solutions. $5 \mathrm{~g}$ of soil sample was measured into a cup. $5 \mathrm{~mL}$ distilled water was added to the sample and the content stirred vigorously for 5 seconds and then allowed to stand for 10 minutes. The electrodes of the $\mathrm{pH}$ meter were dipped in the slurry and the $\mathrm{pH}$ readings taken immediately. Total organic carbon contents were determined by the Chromic acid oxidation method of Black (1965). The organic carbon determined was expressed as percentage of the sample taken, while total organic matter (TOM) levels were examined by multiplying the Total Organic Carbon (TOC) by the factor 1.729 (Black, 1965). Other parameters were determined using their standard methods and procedures. 


\subsection{Pollution Indices}

To evaluate the sediment contamination or pollution by heavy metals, four different assessment indices; Contamination Factor, Pollution Load Index (Hasan et al., 2016), Enrichment Factor, and Geoaccumulation Index (Barbieri, 2016) were estimated. Also, the Correlation Coefficients ( $r$ ) of the heavy metals in the bottom sediments were determined to establish the relationship existing between them.

1) Contamination factor

CF was employed to express the level of metal contamination of the sediments (Abdullah et al., 2015). It represents the individual impact of each trace metal on the sediment (Muzerengi, 2017). It was expressed as:

$$
\mathrm{CF}=\frac{C_{m}(\text { sample })}{\left.C_{m} \text { (background }\right)}
$$

where $C_{m \text { (sample) }}=$ Concentration of the metal in soil sample from the study area; $C_{m \text { (background) }}=$ Concentration of the metal in soil sample from background (Control) area.

Contamination factor and degree of contamination are classified as: $\mathrm{CF}<1$ (low), $1 \leq \mathrm{CF}<3$ (moderate), $3 \leq \mathrm{CF}<6$ (considerable), and $\mathrm{CF} \geq 6$ (very high) (Hassan et al., 2016; Bashir et al., 2014; Abdullah et al., 2011).

\section{2) Pollution load index (PLI)}

The PLI assesses pollution level by considering the joint effect of all the polluting heavy metals in soil or water (Musa et al., 2018). It represents the number of times by which the metal concentration in the soil exceeds the average natural background metal concentration. The PLI was determined as the $n$th root of the $n$ contamination factors $\left(\mathrm{CF}_{n}\right)$ for all the metals multiplied together and calculated (Bashir et al., 2014). It was expressed as:

$$
\mathrm{PLI}=\left(\mathrm{CF}_{1} \times \mathrm{CF}_{2} \times \mathrm{CF}_{3} \times \mathrm{CF}_{4} \ldots \times \mathrm{CF} n\right)^{1} /^{n}
$$

where $\mathrm{CF}=$ contamination factor of each metal, and $n=$ total number of metals.

PLI value of $>1$ indicates a polluted condition and a deterioration of the environmental quality, PLI $<1$ means there is no metal pollution in the area, and PLI value of 1 indicates a baseline level of pollution (Tomlinson et al., 1980; Harikumar et al., 2009; Muzerengi, 2017).

\section{3) Enrichment factor}

EF indicates the presence and intensity of anthropogenic contaminant deposition on surface soil. According to Barbieri (2016), it was calculated by the normalization of one metal concentration in the top soil with respect to the concentration of a reference element. A reference element is an element that is particularly stable in the soil, whose concentration is not influenced or characterized by vertical mobility or degradation phenomena (Barbieri, 2016) such as iron and aluminum. It is often characterized by low occurrence of variability (Muzerengi, 2017). Enrichment Factorwas expressed as:

$$
\mathrm{EF}=\left(\frac{\text { Metal }}{\mathrm{RE}}\right) \text { sample } /\left(\frac{\text { Metal }}{\mathrm{RE}}\right) \text { background }
$$


where $\mathrm{RE}=$ Concentration of metal taken as Reference Element.

EF results are classified as: $0.5 \leq \mathrm{EF} \leq 1.5$ (normal situation/natural weathering processes); $\mathrm{EF} \geq 1.5$ (Significant portion of metals delivered from other sources such as point and non-point pollution and biota).

4) Geoaccumulation index $\left(I_{\text {geo }}\right)$

This was originally proposed by Muller (1979) and has been successfully applied to evaluate heavy metals pollution in sediments (Inengite et al., 2010; Barbieri, 2016). It is expressed as:

$$
\mathrm{I}_{\text {geo }}=\log 2\left(C_{n} / 1.5 B_{n}\right)
$$

where $C_{n}=$ concentration of the metal in the fraction analyzed of the sample, and $B_{n}=$ the concentration of the metal in the same fraction of the sediments in the background (or control) area. The factor (or constant), 1.5 was introduced to minimize the effect of possible variations in the background (control) values which might be attributed to lithologic variations in the soil (Muzerengi, 2017; Pam et al., 2013; Musa et al., 2018). It has seven classes which include: Class 0, with values $<0$ or 0 (no pollution); Class 1 has values from $0-1$ (not polluted to moderately polluted), Class 2 has values from $1-2$ (moderately polluted); Class 3 has values from 2 - 3 (moderately polluted to strongly polluted); Class 4 has values from 3 - 4 (strongly polluted); Class 5 has values from 4 - 5 (strongly polluted to extremely polluted); Class 6 has values $>5$, which indicates an extremely polluted situation and reflects at least a 100-fold Enrichment Factor above background (control) values (Muzerengi, 2017; Barbieri, 2016; Pam et al., 2013).

\section{Results and Discussions}

Seasonal and mean values of physico-chemical parameters analyzed for various sampling stations in study area are in Table 2 while those of the control station are in Table 3.

\subsection{Physico-Chemical Parameters in Bottom Sediments}

\section{1) $\mathrm{pH}$}

Bottom sediment mean $\mathrm{pH}$ ranged from 5.81 at SBS7 to 6.44 at SBS6, and all values were higher than the control (CBS1) value of 5.74 (Table 4). Seasonal values ranged from 5.40 at SBS7 during rainy season (RNS) to 6.74 during late rainy season (LRS) at SBS6 (Table 2). The lower $\mathrm{pH}$ reflected the presence of sulfides such as pyrites $\left(\mathrm{FeS}_{2}\right)$ which when exposed to water and air, form Acid Mine Drain (AMD) that infiltrates surface water bodies and thus reduces the $\mathrm{pH}$ (Galhardi \& Bonotto, 2016). This also affects the $\mathrm{pH}$ of the bottom sediments lying under the surface water.

\section{2) Chloride}

Chloride mean concentrations ranged from 43.30 - $112.33 \mathrm{mg} / \mathrm{kg}$ (SBS6 - SBS3), and only mean value of $\mathrm{Pb}-\mathrm{Zn}$ mine downstream/run-off (SBS6) was lower than the control sediment (CBS1) from Aku stream (Table 4). Seasonal mean chloride concentration was highest in the rainy seasons than the dry seasons in the study 
Table 2. Seasonal values of physico-chemical parameters and heavy metals in bottom sediments.

\begin{tabular}{|c|c|c|c|c|c|c|c|c|c|c|c|c|c|c|c|c|}
\hline \multirow[b]{2}{*}{ Parameters } & \multicolumn{3}{|c|}{ SBS3 } & \multicolumn{5}{|c|}{ SBS6 } & \multicolumn{3}{|c|}{ SBS7 } & \multicolumn{5}{|c|}{ SBS8 } \\
\hline & RNS & LRS & DRS & LDS & RNS & LRS & DRS & LDS & RNS & LRS & DRS & LDS & RNS & LRS & DRS & LDS \\
\hline $\mathrm{pH}$ & 5.80 & 5.85 & 6.43 & 6.53 & 6.70 & 6.74 & 6.21 & 6.10 & 5.40 & 6.00 & 6.09 & 5.74 & 5.60 & 6.24 & 6.70 & 6.61 \\
\hline $\begin{array}{l}\text { Cond. } \\
(\mu \mathrm{S} / \mathrm{cm})\end{array}$ & 1204.00 & 1210.00 & 1780.00 & 1986.00 & 206.00 & 208.00 & 320.00 & 342.00 & 630.00 & 634.00 & 484.84 & 486.00 & 625.00 & 630.00 & 534.80 & 404.00 \\
\hline $\mathrm{Cl}^{-}(\mathrm{mg} / \mathrm{kg})$ & 184.00 & 184.00 & 39.80 & 41.50 & 52.00 & 54.00 & 28.30 & 38.90 & 98.00 & 112.00 & 7.89 & 80.27 & 94.00 & 96.00 & 87.92 & 46.60 \\
\hline $\begin{array}{c}\text { Alkal. } \\
(\mathrm{mg} / \mathrm{kg})\end{array}$ & 0.60 & 0.90 & 1.20 & 1.35 & 0.60 & 0.90 & 0.80 & 0.48 & 0.92 & 0.99 & 1.00 & 0.98 & 0.40 & 0.80 & 2.00 & 1.80 \\
\hline TOC (\%) & 282.71 & 284.71 & 6.88 & 7.81 & 69.27 & 69.30 & 6.71 & 9.10 & 134.50 & 139.10 & 7.29 & 17.41 & 138.00 & 142.09 & 7.11 & 15.56 \\
\hline TOM (\%) & 1.08 & 1.11 & 1.16 & 2.23 & 1.62 & 1.67 & 1.43 & 1.39 & 2.36 & 2.82 & 3.10 & 3.81 & 2.41 & 2.43 & 3.14 & 0.91 \\
\hline $\mathrm{Zn}(\mathrm{mg} / \mathrm{kg})$ & 52.79 & 55.86 & 62.14 & 57.50 & 23.24 & 30.60 & 22.29 & 34.82 & 31.03 & 31.90 & 32.64 & 34.79 & 33.25 & 56.85 & 52.58 & 48.88 \\
\hline $\mathrm{Fe}(\mathrm{mg} / \mathrm{kg})$ & 3321.10 & 3645.30 & 34.00 & 55.80 & 2288.40 & 2362.58 & 35.70 & 40.84 & 2106.80 & 2287.68 & 36.70 & 36.23 & 2062.66 & 2122.70 & 34.80 & 44.60 \\
\hline $\mathrm{Mn}(\mathrm{mg} / \mathrm{kg})$ & 55.83 & 60.80 & 26.70 & 28.50 & 53.60 & 59.87 & 23.10 & 29.90 & 55.06 & 53.76 & 18.10 & 19.70 & 58.10 & 54.72 & 17.40 & 19.00 \\
\hline $\mathrm{Ni}(\mathrm{mg} / \mathrm{kg})$ & 4.69 & 4.89 & 2.61 & 3.88 & 7.83 & 9.83 & 2.59 & 4.19 & 15.96 & 16.98 & 2.33 & 2.59 & 16.84 & 17.12 & 12.41 & 22.40 \\
\hline $\mathrm{Pb}(\mathrm{mg} / \mathrm{kg})$ & 151.34 & 153.12 & 164.92 & 179.53 & 27.54 & 39.06 & 44.62 & 40.80 & 71.94 & 72.16 & 5.29 & 10.36 & 80.63 & 85.81 & 90.87 & 92.10 \\
\hline $\mathrm{Cd}(\mathrm{mg} / \mathrm{kg})$ & 19.38 & 20.98 & 31.39 & 31.85 & 0.49 & 0.50 & 1.42 & 1.64 & 0.73 & 0.72 & 1.31 & 1.74 & 0.78 & 0.80 & 1.36 & 1.66 \\
\hline $\mathrm{Cr}(\mathrm{mg} / \mathrm{kg})$ & 1.45 & 1.43 & 1.41 & 2.20 & 1.34 & 1.32 & 1.18 & 1.90 & 1.16 & 1.12 & 1.32 & 1.30 & 1.21 & 1.19 & 1.30 & 1.86 \\
\hline
\end{tabular}

Table 3. Seasonal and mean values of physico-chemical paraameters and heavy metals in control bottom sediments.

\begin{tabular}{ccccccc}
\hline & & \multicolumn{5}{c}{ CS1 } \\
\hline Parameters & RNS & LRS & DRS & LDS & MEAN & STDEV \\
\hline $\mathrm{pH}$ & 4.50 & 5.80 & 6.35 & 6.30 & 5.74 & 0.86 \\
$\mathrm{EC}(\mu \mathrm{S} / \mathrm{cm})$ & 367.00 & 369.00 & 284.00 & 296.00 & 329.00 & 45.31 \\
Chloride $(\mathrm{mg} / \mathrm{kg})$ & 76.00 & 78.00 & 22.00 & 26.00 & 50.50 & 30.65 \\
Alkal. $(\mathrm{mg} / \mathrm{kg})$ & 0.56 & 0.63 & 1.20 & 1.20 & 0.90 & 0.35 \\
$\mathrm{Nitrate}(\mathrm{mg} / \mathrm{kg})$ & 2.00 & 2.10 & 9.86 & 9.35 & 5.83 & 4.37 \\
$\mathrm{TOC}(\%)$ & 1.36 & 1.42 & 0.72 & 0.70 & 1.05 & 0.39 \\
$\mathrm{TOM}(\%)$ & 2.35 & 2.46 & 1.25 & 1.21 & 1.82 & 0.68 \\
$\mathrm{Cu}(\mathrm{mg} / \mathrm{kg})$ & 6.76 & 7.24 & 2.37 & 2.69 & 4.77 & 2.59 \\
$\mathrm{Zn}(\mathrm{mg} / \mathrm{kg})$ & 26.61 & 26.65 & 2.39 & 2.54 & 14.55 & 13.95 \\
$\mathrm{Fe}(\mathrm{mg} / \mathrm{kg})$ & 2249.10 & 2264.30 & 34.30 & 33.92 & 1145.41 & 1283.23 \\
$\mathrm{Mn}(\mathrm{mg} / \mathrm{kg})$ & 54.06 & 53.86 & 16.90 & 16.98 & 35.45 & 21.37 \\
$\mathrm{Ni}(\mathrm{mg} / \mathrm{kg})$ & 9.49 & 10.21 & 2.68 & 3.88 & 6.57 & 3.84 \\
$\mathrm{~Pb}(\mathrm{mg} / \mathrm{kg})$ & 13.40 & 13.81 & 3.84 & 5.10 & 9.04 & 5.30 \\
$\mathrm{Cd}(\mathrm{mg} / \mathrm{kg})$ & 0.85 & 0.91 & 1.52 & 1.59 & 1.22 & 0.39 \\
$\mathrm{Cr}(\mathrm{mg} / \mathrm{kg})$ & 0.86 & 0.92 & 1.42 & 1.40 & 1.15 & 0.30 \\
\hline
\end{tabular}


Table 4. Mean values of physico-chemical parameters and heavy metals in bottom sediments of study and control areas.

\begin{tabular}{cccccc}
\hline Parameter & SBS3 & SBS6 & SBS7 & SBS8 & Control (CBS1) \\
\hline $\mathrm{pH}$ & 6.15 & 6.44 & 5.81 & 6.29 & 5.74 \\
$\mathrm{EC}(\mu \mathrm{S} / \mathrm{cm})$ & 1545.00 & 269.00 & 558.71 & 548.45 & 329.00 \\
Chloride $(\mathrm{mg} / \mathrm{kg})$ & 112.33 & 43.30 & 74.54 & 81.13 & 50.50 \\
Alkal. $(\mathrm{mg} / \mathrm{kg})$ & 1.01 & 0.70 & 0.97 & 1.25 & 0.90 \\
Nitrate $(\mathrm{mg} / \mathrm{kg})$ & 7.90 & 7.13 & 6.83 & 5.90 & 5.83 \\
$\mathrm{TOC}(\%)$ & 0.81 & 0.88 & 1.75 & 1.29 & 1.05 \\
$\mathrm{TOM}(\%)$ & 1.40 & 1.53 & 3.02 & 2.22 & 1.82 \\
$\mathrm{Cu}(\mathrm{mg} / \mathrm{kg})$ & 50.93 & 4.74 & 7.71 & 28.71 & 4.77 \\
$\mathrm{Zn}(\mathrm{mg} / \mathrm{kg})$ & 57.07 & 26.78 & 32.82 & 47.89 & 14.55 \\
$\mathrm{Fe}(\mathrm{mg} / \mathrm{kg})$ & 1764.05 & 1181.88 & 1116.85 & 1066.19 & 1145.41 \\
$\mathrm{Mn}(\mathrm{mg} / \mathrm{kg})$ & 42.96 & 41.62 & 36.66 & 37.31 & 35.45 \\
$\mathrm{Ni}(\mathrm{mg} / \mathrm{kg})$ & 4.02 & 6.11 & 9.47 & 17.19 & 6.57 \\
$\mathrm{~Pb}(\mathrm{mg} / \mathrm{kg})$ & 162.23 & 38.01 & 39.94 & 87.35 & 9.04 \\
$\mathrm{Cd}(\mathrm{mg} / \mathrm{kg})$ & 25.90 & 1.01 & 1.13 & 1.15 & 1.22 \\
$\mathrm{Cr}(\mathrm{mg} / \mathrm{kg})$ & 1.62 & 1.44 & 1.23 & 1.39 & 1.15 \\
\hline
\end{tabular}

area (Table 2). High concentration of chloride could be due to the agricultural activities such as pesticides from farm soils, inputs from mines and other waste dumps/discharges, and leachates from chloride-rich rocks in the area. It could also be due to presence of organic matter, possibly from animal origin (Tresh et al., 1944).

\section{3) Electrical conductivity (EC)}

Bottom sediments had a range of 269.00 to $1545.00 \mu \mathrm{S} / \mathrm{cm}$, with SBS3 (mine pit) having highest mean value. Control mean was higher than the value of SBS6 (Table 4). Also, mean rainy season concentrations were higher than those of dry seasons at SBS7, SBS8, and CBS1 (control sediment) while the reverse was the case at SBS3 and SBS6 (Table 2). The high electrical conductivity recorded in bottom sediments could be due to presence of high concentration of charged ions (both cations and anions) in the area (Chukwuemeka et al., 2017).

\section{4) Alkalinity}

Alkalinity mean values ranged from $0.70-1.25 \mathrm{mg} / \mathrm{kg}$, with sediments from Iyiogwe stream (SBS8) having the maximum value. Also, control (CBS1) mean value was only higher than that of (SBS6) (Table 3). Seasonal mean concentrations during dry seasons were higher than those of rainy seasons at all stations including the control (CBS1), exception of SBS6 where the reverse was the case (Table 2 and Table 3).

\section{5) Nitrate}

Mean nitrate concentrations ranged between $5.90-7.90 \mathrm{mg} / \mathrm{kg}$, with highest mean recorded at the mine pit (SBS3). However, all recorded mean values from 
the study area were higher than that of the control (CBS1) (Table 3). Also, seasonal nitrate concentrations in bottom sediments, were in the order of RNS < LRS $<$ DRS $<$ LDS, exception of the control (CBS1) and SBS8, whose concentrations decreased during the late dry season (LDS) (Table 2 and Table 3 ).

\section{6) Total organic carbon (TOC)}

TOC mean concentrations ranged between $0.81-1.75 \mathrm{mg} / \mathrm{kg}$ in the order of SBS3 < SBS6 < SBS8 < SBS7, and control (CBS1) value was higher than those of SBS3 and SBS6 (Table 4). Seasonal TOC concentrations were sharply higher during the rainy seasons than in the dry seasons (Table 2). High TOC could be due to increased rates of biodegradation especially during rainy seasons which also depended on increased availability of water from rainfall.

\section{7) Total organic matter (TOM)}

According to Pam et al. (2013) metals are mobilized by soil organic matter, at weakly acidic and alkaline conditions, to form insoluble or soluble organic metal complexes, while at strongly acidic conditions they are immobilized by the organic matter. Mean TOM ranged between $1.40-3.02 \mathrm{mg} / \mathrm{kg}$ in the order of SBS3 $<$ SBS6 < SBS8 < SBS7 in the study area, and control (CBS1) mean concentration was higher than those of SBS3 and SBS6 (Table 4). Seasonal concentrations were highest during the late rainy season (LRS) at all stations including control (CBS1) (Table 2 and Table 3). The relatively high TOM at SBS8, SBS7 and SBS6 could be due to increased rate of biodegradation of trees, shrubs and many other soil or pond-dwelling plant and animal materials prevalent at these sampling stations.

\subsection{Heavy Metals in Bottom Sediments}

Mean heavy metal concentrations in bottom sediments from the study area also varied between rainy and dry seasons, as higher concentrations were recorded during the rainy seasons at some stations and during the dry seasons at other stations.

\section{1) Copper}

Highest mean concentration of copper in bottom sediments was $50.93 \mathrm{mg} / \mathrm{kg}$ at SBS3 (Pb-Zn mine pit) while the lowest concentration was $4.74 \mathrm{mg} / \mathrm{kg}$ at SBS6 ( $\mathrm{Pb}-\mathrm{Zn}$ mine downstream/run-off), with mean value only lower than that of the control (CBS1) (Table 4). Highest seasonal value of $\mathrm{Cu}$ was obtained at SBS3 during the late dry season (LDS) while the lowest value was at SBS6 in the dry season (DRS) (Table 2). Mean concentrations were within standard values, exception of the mine pit which had a mean concentration of $50.93 \mathrm{mg} / \mathrm{kg}$. This was higher than the standard values of DPR (2002), Dutch Target and Intervention Values (2000), and China (Wang \& Shan, 2013) but lower than the guidelines of Canada (CCME, 2001) (Table 5). Apart from contributions from natural sources, copper inputs to bottom sediments could result from mine wastes and discharges from the mine pits; and also from farming activities, as its compounds could be added to fertilizers and animal feeds to serve as nutrient to support plant and animal growth (Jumbe \& Nandini, 2009). 
Table 5. Target values/limits for heavy metals in soil/sediment.

\begin{tabular}{cccccc}
\hline Parameter & DPR $^{\mathrm{a}}$ & DUTCH $^{\mathrm{b}}$ & CHINA $^{\mathrm{c}}$ & CANADA $^{\mathrm{d}}$ & UK $^{\mathrm{e}}$ \\
\hline Copper $(\mathrm{mg} / \mathrm{kg})$ & 36.00 & 36.00 & 35.00 & 63.00 & - \\
Zinc $(\mathrm{mg} / \mathrm{kg})$ & 140.00 & 140.00 & 100.00 & 200.00 & - \\
Iron $(\mathrm{mg} / \mathrm{kg})$ & - & - & - & - & - \\
Manganese (mg/kg) & - & - & - & - & - \\
Nickel (mg/kg) & 35.00 & 35.00 & 40.00 & 50.00 & - \\
Lead (mg/kg) & 85.00 & 85.00 & 35.00 & 70.00 & 500.00 \\
Cadmium (mg/kg) & 0.80 & 0.80 & 0.20 & 1.40 & 1.00 \\
Chromium (mg/kg) & 100.00 & 100.00 & 90.00 & 64.00 & 25.00 \\
\hline
\end{tabular}

Sources: $\mathrm{a}=$ DPR (2002); $\mathrm{b}=$ Dutch Target and Intervention Values (2000); c = CHINA (Wang \& Shan, 2013); d = CANADA (CCME, 2001); e = UK (EQS, 2017).

\section{2) Zinc}

Mean zinc concentrations range was from 26.78 - $57.07 \mathrm{mg} / \mathrm{kg}$ (SBS6 - SBS3); and the control (CBS1) mean level was found to be lower than those from the study area (Table 4). Mean levels at the various stations, including the control were within referenced standard guidelines/limits (Table 5). According to Wuana \& Okieimen (2011), water-soluble zinc in soils can contaminate groundwater, and that, due to the accumulation of $\mathrm{Zn}$ in soils, plants often take up high amounts of $\mathrm{Zn}$ that are too much for their systems to synthesize.

\section{3) Iron}

The highest mean concentration of iron in bottom sediments was 1764.05 $\mathrm{mg} / \mathrm{kg}$ at SBS3 (mine pit) while the lowest was $1066.19 \mathrm{mg} / \mathrm{kg}$ at SBS8 (Iyiogwe stream); and the mean control (CBS1) value was found to be higher than those of SBS7 (NNPC pipeline stream) and SBS8 (Table 4). Also, iron had higher mean concentrations in the rainy seasons than the dry seasons in both study and control areas; and a sharp decrease in the dry season values compared to those of the rainy seasons (Table 2).

\section{4) Manganese}

Mean concentrations of Mn ranged from 36.66 - $42.96 \mathrm{mg} / \mathrm{kg}$ (SBS7 - SBS3); and control (CBS1) mean level was found to be lower than those from the study area (Table 4). Manganese also had higher mean concentrations during the rainy seasons than the dry seasons, and there was also a sharp decrease in the dry seasons (DRS and LDS) values compared to those of the rainy seasons (RNS and LRS) at all stations (Table 2). Mn occurs naturally in many types of rocks and soil (Izomoh \& Akpambang, 2017). The high level of Mn found in bottom sediments from both study and control areas could thus be attributed to its high natural occurrence in the surrounding rocks and soils in the area.

\section{5) Nickel}

The highest mean level of nickel in bottom sediments was $17.19 \mathrm{mg} / \mathrm{kg}$ at SBS8 (Iyiogwe stream) while the lowest was $4.02 \mathrm{mg} / \mathrm{kg}$ at SBS3 (mine pit). The control (CBS1) mean value was higher than those of SBS3 and SBS6 (Table 4). 
Comparison with standard guidelines showed that nickel concentrations in bottom sediments were within limits of DPR (2002), Dutch Target and Intervention Values (2000), China (Wang \& Shan, 2013), Canada (CCME, 2001) and UK (EQS, 2017) (Table 5). Mean Ni levels were also below the estimated toxic level of $\mathrm{Ni}(100 \mathrm{mg} / \mathrm{kg})$ in agricultural soils (Ezeh \& Chukwu, 2011).

\section{6) Lead}

Mean lead concentrations in the bottom sediments ranged from $38.01-162.23$ $\mathrm{mg} / \mathrm{kg}$, with SBS3 (mine pit) having the highest lead concentration and SBS6 (mine discharge downstream/run-off), having the lowest. Control (CBS1) mean level was found to be lower than those from study area (Table 4). When compared with standard values/limits, mean $\mathrm{Pb}$ concentrations in bottom sediments from mine pit (SBS3) was found to be higher than limits of DPR (2002), Dutch Target and Intervention Values (2000), China (Wang \& Shan, 2013), and Canada (CCME, 2001) but lower than that of UK (EQS, 2017), while other stations, including the control, had values within the standard values/limits (Table 5). In the presence of high sulfide concentration, lead under reducing conditions, forms lead sulfide ( $\mathrm{PbS}$ ) which is the most stable solid form within the soil matrix. Lead gets into the human system through inhalation and ingestion, which results in accumulation in the brain and consequently cause poisoning (known as plumbism) that may also lead to death (Wuana \& Okieimen, 2011).

\section{7) Cadmium}

The mean concentrations of cadmium ranged from $1.01 \mathrm{mg} / \mathrm{kg}$ at SBS6 (mine discharge downstream/run-off) to $25.90 \mathrm{mg} / \mathrm{kg}$ at SBS3 (mine pit). However, only SBS3 was found to have a higher mean cadmium concentration than the control (CBS1), amongst the bottom sediments from study area (Table 4). The $\mathrm{Pb}-\mathrm{Zn}$ mine pit/pond (SBS3) recorded a mean level $(25.90 \mathrm{mg} / \mathrm{kg})$ higher than the referenced standards guidelines (Table 5).

\section{8) Chromium}

Bottom sediments had minimum mean chromium value of $1.23 \mathrm{mg} / \mathrm{kg}$ at SBS7 (NNPC pipeline stream) while the maximum was $1.62 \mathrm{mg} / \mathrm{kg}$ at the mine pit (SBS3). All stations from the study area recorded higher mean chromium concentration than the control (CBS1) from Aku stream (Table 4). Seasonal mean concentrations were higher during the dry seasons than in the rainy seasons (Table 2). Also, all stations from study and control areas were within standards guidelines (Table 5). Chromium is found mainly in Chrome-Iron ore $\left(\mathrm{FeO}-\mathrm{Cr}_{2} \mathrm{O}_{3}\right)$. It is considered non-essential for plants, but essential for animals (Jumbe \& N\&ini, 2009).

\subsection{Evaluation of Pollution Indices for Bottom Sediment Qualities}

\section{1) Contamination factor $(\mathrm{CF})$}

Contamination factor was estimated using mean concentrations of the heavy metals in the study areas with their concentrations from the control sample stations used as the background values (Pam et al., 2013) on Equation (1). CF values for bottom sediments (Table 6) show that Manganese and Chromium con- 
taminations were at moderate degrees of contamination in the study area; Copper was very high at the mine pit (SBS3) and Iyiogwe stream (SBS8) but moderate at the mine downstream/run-off (SBS6) and NNPC pipeline stream (SBS7); $\mathrm{Zn}$ was at moderate levels at SBS6 and SBS7 but considerable at SBS3 and SBS8; Iron was at low degree of contamination at SBS7 and SBS8 while at SBS3 and SBS6, it was moderate; Ni contaminations were low at SBS3 and SBS6 but moderate at SBS7 and SBS8; Pb was at a very high degree of contamination at SBS3 and SBS8 but considerable at SBS6 and SBS7; while Cd contamination was also at a very high degree but low at SBS6, SBS7 and SBS8. The high CF values were indications that the heavy metals at the various sampling stations, except iron (Fe) were from anthropogenic sources, as reported by Akoto et al. (2008) that CF values between 0.5 and 1.5 indicate that the metal is entirely from crust materials or natural sources while values above 1.5 could come from anthropogenic sources.

\section{2) Pollution Load Index (PLI)}

This model (Equation (2)) proposed by Tomlinson et al. (1980), according to Musa et al. (2018), represents the number of times by which the metal concentration in the soil exceeds the average natural background metal concentration; and gives an indication of the total level of metal toxicity in a given sample (Muzerengi, 2017). PLI values for the sampling stations were greater than 1 (i.e. PLI > 1) (Table 7), which indicated polluted conditions and deterioration of the bottom sediment qualities, with high degree of heavy metal contamination in the study area. Most polluted site by PLI estimation is the Pb- $\mathrm{Zn}$ mine site (SBS3).

Table 6. Contamination factors (CF) of heavy metals in bottom sediments.

\begin{tabular}{ccccc}
\hline Heavy Metal & SBS3 & SBS6 & SBS7 & SBS8 \\
\hline Copper & 10.69 & 1.00 & 1.62 & 6.03 \\
Zinc & 3.92 & 1.84 & 2.26 & 3.29 \\
Iron & 1.54 & 1.03 & 0.98 & 0.93 \\
Manganese & 1.21 & 1.17 & 1.03 & 2.62 \\
Nickel & 0.61 & 0.93 & 1.44 & 9.67 \\
Lead & 17.95 & 4.21 & 4.42 & 0.94 \\
Cadmium & 21.27 & 0.83 & 0.92 & 1.21 \\
Chromium & 1.41 & 1.25 & 1.07 & \\
\hline
\end{tabular}

Table 7. Pollution load index (PLI) of heavy metals in bottom sediments.

\begin{tabular}{cccc}
\hline Sampling Stations & PLI & Level & Indication \\
\hline SBS3 & 3.31 & $>1$ & Polluted area \\
SBS6 & 1.32 & $>1$ & Polluted area \\
SBS7 & 1.44 & $>1$ & Polluted area \\
SBS8 & 2.07 & $>1$ & Polluted area \\
\hline
\end{tabular}




\section{3) Enrichment Factor (EF)}

EF of the heavy metals in the bottom sediments were assessed using Equation (3), with Iron ( $\mathrm{Fe}$ ) as the reference element (RE) since it is often characterized by low occurrence of variability (Muzerengi, 2017), and particularly stable in the soil and its concentration is not influenced or characterized by vertical mobility or degradation phenomena (Barbieri, 2016). EF values (Table 8) showed that at SBS3, Fe, Mn, Ni and $\mathrm{Cr}$ concentrations come entirely from natural weathering processes of rocks and other available substances, as their $\mathrm{EF}$ values were within $0.5 \leq \mathrm{EF} \leq 1.5$ range, while $\mathrm{Cu}, \mathrm{Zn}, \mathrm{Pb}$ and $\mathrm{Cd}$ concentrations were influenced by anthropogenic sources, with EF values above the range. At SBS6, EEF values for $\mathrm{Cu}, \mathrm{Fe}, \mathrm{Mn}, \mathrm{Ni}, \mathrm{Cd}$ and $\mathrm{Cr}$ were within $0.5 \leq \mathrm{EF} \leq 1.5$, while those of $\mathrm{Zn}$ and $\mathrm{Pb}$ were above the range. EF values at SBS7 also indicated that $\mathrm{Fe}, \mathrm{Mn}, \mathrm{Ni}, \mathrm{Cd}$ and $\mathrm{Cr}$ were within the range of $0.5 \leq \mathrm{EF} \leq 1.5$, while those of $\mathrm{Cu}, \mathrm{Zn}$ and $\mathrm{Pb}$ had $\mathrm{EF}$ values above the range. At SBS8, $\mathrm{EF}$ values for $\mathrm{Fe}, \mathrm{Mn}, \mathrm{Cd}$ and $\mathrm{Cr}$ were within the range $(0.5 \leq \mathrm{EF} \leq 1.5)$ which indicated a natural cause of weathering for their concentration, while the values of $\mathrm{Cu}, \mathrm{Zn}, \mathrm{Ni}$ and $\mathrm{Pb}$ were above the range, indicating rather significant contribution from anthropogenic sources to their concentrations (Pam et al., 2013). Order of anthropogenic inputs in bottom sediments from the mine pit/pond (SBS3) was $\mathrm{Cd}>\mathrm{Pb}>\mathrm{Cu}>\mathrm{Zn}>\mathrm{Fe}>\mathrm{Cd}>\mathrm{Mn}>\mathrm{Ni}$, while at SBS6 it was $\mathrm{Pb}>\mathrm{Zn}>\mathrm{Cr}>\mathrm{Mn}>\mathrm{Fe}>\mathrm{Cu}>\mathrm{Ni}>\mathrm{Cd}$. At SBS7, the order was $\mathrm{Pb}>\mathrm{Zn}>\mathrm{Cu}>\mathrm{Ni}>\mathrm{Cr}>\mathrm{Mn}>\mathrm{Fe}>\mathrm{Cd}$, while at SBS8 it was $\mathrm{Pb}>\mathrm{Cu}>$ $\mathrm{Zn}>\mathrm{Ni}>\mathrm{Cr}>\mathrm{Mn}>\mathrm{Cd}>\mathrm{Fe}$.

\section{4) Geoaccumulation index $\left(\mathrm{I}_{\text {geo }}\right)$}

Based on the model (Equation (4)) and its seven-class categorization of heavy metal pollution, as proposed by Muller (1979) (Inengite et al., 2010; Fagbote \& Olanipekun, 2010; Izomoh \& Akpambang, 2017), the intensities of heavy metal contamination and pollution in bottom sediments in Ihetutu minefield were also assessed. Igeo values (Table 9 ) indicated that Copper was $<0$ (no pollution) at SBS6, 0 - 1 (unpolluted to moderate pollution) at SBS7, and 2 - 3 (moderate pollution to high pollution) at SBS3 and SBS8; Zn was in the range of 0 - 1 (unpolluted to moderate pollution) at SBS6 and SBS7 but $1-2$ (moderate pollution) at SBS3 and SBS8; Fe was also $0-1$ (no pollution to moderate pollution) at SBS3 but $<0$ (no pollution) at SBS6, SBS7 and SBS8; Mn and Cr were $<0$ indicating no pollution by the two metals. Ni was also $<0$ (no pollution) at SBS3, SBS6, SBS7 but $0-1$ (no pollution to moderate pollution) at SBS8; Pb was $3-4$ (high pollution) at SBS3, 2 - 3 (moderate pollution to high pollution) at SBS8, and 1 - 2 (moderate pollution) at SBS6 and SBS7. Cd was also $3-4$ (high pollution) at SBS3 but $<0$ (no pollution) at SBS6, SBS7 and SBS8.

\subsection{Correlations}

\section{Among heavy metals in bottom sediments}

Highest positive correlation $(\mathrm{r}=0.992)$ was between $\mathrm{Pb}$ and $\mathrm{Cu}$ while the highest negative correlation $(\mathrm{r}=-0.789)$ was between $\mathrm{Ni}$ and $\mathrm{Mn}$. Correlations determine the relationships between the sources of heavy metals, and positive 
correlations point to similar sources of heavy metal pollution (Inengite et al., 2010; Dragovi et al., 2008). Thus, the high positive correlations between $\mathrm{Pb}$ and $\mathrm{Cu}, \mathrm{Zn}$ and $\mathrm{Cu}, \mathrm{Pb}$ and $\mathrm{Cd}, \mathrm{Fe}$ and $\mathrm{Cd}$, etc. (Table 10), point to common sources (Bhuiyan et al., 2009; Mohsen \& Alireza 2014) such as anti-corrosion materials on pipes and other metal surfaces; and from solid or liquid waste materials in the mining areas such as tailings, cables, lubricating oils, automobile tires, batteries and metal alloys used to harden engine parts. There was also strong positive correlations between $\mathrm{Pb}$ and $\mathrm{Zn}(\mathrm{r}=0.950)$ which points to a common source; the $\mathrm{Pb}-\mathrm{Zn}$ mines where the two metals are the most prevalent heavy metals hugely extracted from the Ihetutu mines.

Table 8. Enrichment factor (EF) of heavy metals in bottom sediments.

\begin{tabular}{ccccc}
\hline Heavy Metal & SBS3 & SBS6 & SBS7 & SBS8 \\
\hline Copper & 6.94 & 0.96 & 1.66 & 6.47 \\
Zinc & 2.55 & 1.78 & 2.31 & 3.54 \\
Iron & 1.00 & 1.00 & 1.00 & 1.00 \\
Manganese & 0.79 & 1.14 & 1.06 & 1.13 \\
Nickel & 0.40 & 0.9 & 1.48 & 2.81 \\
Lead & 11.66 & 4.08 & 4.53 & 10.38 \\
Cadmium & 13.81 & 0.81 & 0.95 & 1.01 \\
Chromium & 0.92 & 1.21 & 1.09 & 1.30 \\
\hline
\end{tabular}

Table 9. Geoaccummulation index $\left(\mathrm{I}_{\text {geo }}\right)$ of heavy metals in bottom sediments.

\begin{tabular}{ccccc}
\hline Heavy Metal & SBS3 & SBS6 & SBS7 & SBS8 \\
\hline Copper & 2.83 & -0.60 & 0.11 & 2.01 \\
Zinc & 1.39 & 0.30 & 0.58 & 1.13 \\
Iron & 0.04 & -0.54 & -0.62 & -0.69 \\
Manganese & -0.30 & -0.36 & -0.54 & -0.51 \\
Nickel & -1.29 & -0.69 & -0.06 & 0.81 \\
Lead & 3.58 & 1.49 & 1.56 & 2.69 \\
Cadmium & 3.82 & -0.86 & -0.69 & -0.67 \\
Chromium & -0.09 & -0.27 & -0.49 & -0.32
\end{tabular}

Table 10. Correlation of heavy metals in bottom sediments in ihetutu minefield.

\begin{tabular}{ccccccccc}
\hline & $\mathrm{Cu}$ & $Z n$ & $F e$ & $M n$ & $N i$ & $P b$ & $C d$ & $C r$ \\
\hline $\mathrm{Cu}$ & 1 & & & & & & & \\
$\mathrm{Zn}$ & 0.980 & 1 & & & & & & \\
$\mathrm{Fe}$ & 0.794 & 0.670 & 1 & & & & & \\
$\mathrm{Mn}$ & 0.442 & 0.259 & 0.788 & 1 & & & & \\
$\mathrm{Ni}$ & -0.126 & 0.056 & -0.702 & -0.789 & 1 & & & \\
$\mathrm{~Pb}$ & 0.992 & 0.950 & 0.862 & 0.536 & -0.246 & 1 & & \\
$\mathrm{Cd}$ & 0.869 & 0.770 & 0.989 & 0.706 & -0.594 & 0.921 & 1 & \\
$\mathrm{Cr}$ & 0.779 & 0.653 & 0.847 & 0.884 & -0.489 & 0.828 & 0.832 & 1 \\
\hline
\end{tabular}




\subsection{Analysis of Variance (ANOVA)}

ANOVA was performed using Microsoft Office Excel (2007), on the means of the different stations, at a significance level, $\alpha=0.05$. The results showed that there were no statistically significant differences in mean of the parameters among the sampling stations in the study area, as $p$-values (0.644) was higher than the significance level $(\alpha=0.05)$.

\section{Conclusion}

The evaluation carried out on bottom sediments in Ihetutu minefield, using pollution indices/models to estimate the levels of heavy metal contaminations/enrichment confirmed that the bottom sediments of the pits/streams in the study area were all contaminated to various degrees by heavy metals through point and non-point anthropogenic sources. Bottom sediments were found to be highly polluted when compared to background (pre-mining) values obtained from a control site in Uturu. Heavy metals pollution in the area was in the order of $\mathrm{Fe}>\mathrm{Pb}>\mathrm{Zn}>\mathrm{Mn}>$ $\mathrm{Cu}>\mathrm{Ni}>\mathrm{Cd}>\mathrm{Cr}$. Generally, the level of deterioration of bottom sediment qualities among the sampling stations, in terms of heavy metals contamination, was in the order of $\mathrm{Pb}-\mathrm{Zn}$ mine pit (SBS3) > Iyiogwe stream (SBS8) > NNPC pipeline (SBS7) $>\mathrm{Pb}-\mathrm{Zn}$ downstream/run-off (SBS6). Compared to standard target values, bottom sediments from Ihetutu minefield were found to be highly polluted with $\mathrm{Pb}, \mathrm{Zn}$ and $\mathrm{Cu}$ especially at the mine site. The study covered only some few rivers, streams and mine pits/ponds in the area due to denial of access to others by the mining companies. Further research should be carried out on heavy metals, and streams and mine pits/ponds not covered in this study; and the health impact of these contaminants on the bottom sediment dwelling organisms in the study area.

\section{Conflicts of Interest}

The authors declare no conflicts of interest regarding the publication of this paper.

\section{References}

Abdullah, M. Z., Saat, A., \& Hamzah, Z. (2011). Optimization of Energy Dispersive X-Ray Fluorescence Spectrometer to Analyze Heavy Metals in Moss Samples. American Journal of Engineering and Applied Sciences, 4, 355-362.

https://doi.org/10.3844/ajeassp.2011.355.362

Ahmadipour, F., Bahramifar, N., \& Ghasempouri, S. M. (2014). Fractionation and Mobility of Cadmium and Lead in Soils of Amol Area in Iran, Using the Modified BCR Sequential Extraction Method. Chemical Speciation Bioavailability, 26, 31-36. https://doi.org/10.3184/095422914X13884321932037

American Society of Testing and Materials (ASTM D1971/4691) (2016). Standard Practices for Digestion of Water Samples for Determination of Metals by Flame Atomic Absorption, Graphite Furnace Atomic Absorption, Plasma Emission Spectroscopy, or Plasma Mass Spectrometry. West Conshohocken, PA: ASTM International. 
Barbieri, M. (2016). The Importance of Enrichment Factor (EF) and Geoaccumulation Index (Igeo) to Evaluate the Soil Contamination. Journal of Geology and Geophysics, 5, 237. https://www.omicsonline.org/geology-geosciences.php https://doi.org/10.4172/2381-8719.1000237

Bashir, I. M., Zakari, Y. I., Ibeanu, I. G. E., \& Sadiq, U. (2014). Assessment of Heavy Metal Pollution in Flooded Soil of Kudenda, Kaduna State. Nigeria. American Journal of Engineering Research, 3, 197-204.

Bhuiyan, M., Parvez, L., Islam, M., Dampare, S., \& Suzuki, S. (2009). Heavy Metal Pollution of Coal Mine-Affected Agricultural Soils in the Northern Part of Bangladesh. Journal of Hazardous Materials, 173, 384-392. https://doi.org/10.1016/j.jhazmat.2009.08.085

Black, C. A. (1965). Method of Analysis. Agronomy No. 9, Part 2, Madison, WI: American Society of Agronomy. https://doi.org/10.2134/agronmonogr9.1

Canadian Council of Ministers of the Environment (CCME) (2001). Canadian Soil Quality Guidelines for the Protection of Environmental and Human Health: Summary Tables. In Canadian Environmental Quality Guidelines, 1999 (pp. 1-3). Winnipeg: Canadian Council of Ministers of the Environment.

Chukwuemeka, A. N., Ngozi, V. E., Chukwuemeka, I. S., \& Wirnkor, V. A. (2017). Physicochemical Properties and Selected Metals in Soils of Ohaji-Egbema, Imo State, Nigeria. World News of Natural Sciences, 10, 39-48.

Department of Petroleum Resources (DPR) (2002). Environmental Guidelines and Standards for the Petroleum Industry in Nigeria (EGASPIN) (p. 279). Abuja: Ministry of Petroleum Resources.

Dragovi, S., Mihailovi, N., \& Gaji, B. (2008). Heavy Metals in Soils: Distribution, Relationship with Soil Characteristics and Radionuclides and Multivariate Assessment of Contamination Sources. Chemosphere, 72, 491-495.

https://doi.org/10.1016/j.chemosphere.2008.02.063

Dutch Target and Intervention Values (2000) (the New Dutch List). Annexes. Circular on Target Values and Intervention Values for Soil Remediation.

http://esdat.net/Environmental\%20Standards/Dutch/annexS_I2000Dutch\%20Environ mental\%20Standards.pdf

Elom, N. I. (2018). Lead (Pb) Mining in Ebonyi State, Nigeria: Implications for Environmental and Human Health Risk. International Journal of Environment and Pollution Research, 6, 24-32.

Environment Quality Standards (EQS) (2017). Limit and Guideline Values for Contaminated Sites. European Union-Financed INSURE Project Report.

Ezeh, H. N., \& Chukwu, E. (2011). Small Scale Mining and Heavy Metals Pollution of Agricultural Soils: The Case of Ishiagu Mining District, South Eastern Nigeria. Journal of Geology and Mining Research, 3, 87-104.

Ezekwe, I. C. (2009). A Geology of the Okigwe Area of South Eastern Nigeria. Unpublished PGD Thesis, Department of Geological Sciences, Awka: Nnamdi Azikiwe University.

Fagbote, E. O., \& Olanipekun, E. O. (2010). Evaluation of the Status of Heavy Metal Pollution of Soil and Plant (Chromolaena odorata) of Agbadu Bitumen Deport Area, Nigeria. American-Eurasian Journal of Scientific Research, 5, 241-248.

Galhardi, J. A., \& Bonotto, D. M. (2016). Hydrogeochemical Features of Surface Water and Groundwater Contaminated with Acid Mine Drainage (AMD) in Coal Mining Areas: A Case Study in Southern Brazil. Environmental Science and Pollution Research, 23, 18911-18927. https://doi.org/10.1007/s11356-016-7077-3 
Harikumar, P. S., Nasi,r U. P., \& Mujeebu Rahma, M. P. (2009). Distribution of Heavy Metals in the Core Sediments of a Tropical Wetland System. International Journal of Environmental Science and Technology, 6, 225-232.

https://doi.org/10.1007/BF03327626

Hassan, M. R., Khan, M. Z. H., Khan, M., Aktar, S., Rahman, M., Hossain, F., \& Hassan, A. S. M. M. (2016). Heavy Metals Distribution and Contamination in Surface Water of the Bay of Bengal Coast. Cogent Environmental Science, 2, Article ID: 1140001. https://doi.org/10.1080/23311843.2016.1140001

Imo State Ministry of Works and Transport (IMWT) (1984). Atlas of Imo State Nigeria. Domegge di Cadore: $\mathrm{C}$ and G Company.

Inengite, A. K., Oforka, N. C., \& Osuji, L. C. (2010). Survey of Heavy Metals in Sediments of Kolo Creek in the Niger Delta, Nigeria. African Journal of Environmental Science and Technology, 4, 558-566.

International Atomic Energy Agency (IAEA) (2003). Collection and Preparation of Bottom Sediment Samples for Analysis of Radionuclides and Trace Elements. IAEA-TECDOC-1360.

Izomoh, A. S., \& Akpambang, V. O. E. (2017). Physiochemical Properties and Levels of Heavy Metals in Top Soils of Selected Urban Areas in Akure Metropolis, Nigeria. International Journal of Scientific and Engineering Research, 8, 883-904.

Jumbe, A. S., \& Nandini, N. (2009). Heavy Metals Analysis and Sediment Quality Values in Urban Lakes. American Journal of Environmental Sciences, 5, 678-687. https://doi.org/10.3844/ajessp.2009.678.687

Kasich, J., Taylor, M., \& Nally, S. J. (2012). Sediment Sampling Guide and Methodologies (3rd ed.). Columbus, OH: Ohio Environmental Protection Agency, Division of Surface Water.

Mohsen, N., \& Alireza, P. (2014). Application of Geoaccumulation Index and Enrichment Factor for Assessing Metal Contamination in the Sediments of Hara Biosphere Reserve, Iran. Chemical Speciation and Bioavailability, 26, 99-105. https://doi.org/10.3184/095422914X13951584546986

Muller, G. (1979). Schwermetalle in den Sedimenten des Rheins Veranderungen seit 1971. Umschau, 79, 778-783.

Musa, O. W., Ishaq, S. E., Wuana, A. R., \& Ogah, E. (2018). Heavy Metals Accumulation in Soil and Groundwater from a Waste Dumpsite in Makurdi, Nigeria Using Cold Vapour Method. FULafia Journal of Science and Technology, 3, 93-99.

Muzerengi, C. (2017). Enrichment and Geoaccumulation of Pb, Zn, As, Cd and Cr in Soils near New Union Gold Mine, Limpopo Province of South Africa. In C. Wolkersdorfer, L. Sartz, M. Sillanpää, \& A. Häkkinen (Eds.), Mine Water and Circular Econo$m y$ (pp. 720-727). Finland: Lappeenranta.

Nwaugo, V. O., Obiekezie, S. O., \& Etok, C. A. (2007). Post Operational Effects of Heavy Metal Mining on Soil Quality in Ishiagu, Ebonyi State. International Journal of Biotechnology and Allied Sciences, 2, 242-246.

Osuocha, K. U., Akubugwo, E. I., Chinyere, G. C., \& Ugbogu, E. A. (2015). Seasonal Impact on Physicochemical Characteristics and Enzymatic Activities of Ishiagu Quarry Mining Effluent Discharge Soils. International Journal of Current Biochemistry Research, 3, 55-66.

Pam, A. A., Sha'Ato, R., \& Offem, J. O. (2013). Evaluation of Heavy Metals in Soils around Auto Mechanic Workshop Clusters in Gboko and Makurdi, Central Nigeria. Journal of Environmental Chemistry and Ecotoxicology, 5, 298-306.

Radulescu, C., Dulama, I. D., Stihi, C., Ionita, I., Chilian, A., Necula, C., \& Chelarescu, E. D. (2014). Determination of Heavy Metal Levels in Water and Therapeutic Mud by Atomic Absorption Spectrometry. Romanian Journal of Physics, 59, 1057-1066.

Tomlinson, D., Wilson, J., Harris, C., \& Jeffrey, D. (1980). Problems in the Assessment of Heavy Metal Levels in Estruaries and the Formation of a Pollution Index. Helgolander Meeresuntersuchungen, 33, 566-575. https://doi.org/10.1007/BF02414780 
Tresh, J. C., Suckling, E. V., \& Beale, J. F. (1944). Chemical and Zoopklankton Studies of Lentic Habitats in North Eastern New South Wales. Australian Journal Marine Freshwater Research, 21, 11-33. https://doi.org/10.1071/MF9700011

Wang, G., \& Shan, Y. (2013). Soil Environmental Standards/Screening Values in China. International Committee on Contaminated Land. Durban: Environmental Affairs Department.

http://www.iccl.ch/download/durban_2013/Slides_ICCL_2013_Meeting/I_C2_ICCL_2 013_GQWANG_10OCT2013@DURBAN_SA.pdf

Wuana, R. A., \& Okieimen, F. E. (2011). Heavy Metals in Contaminated Soils: A Review of Sources, Chemistry, Risks and Best Available Strategies for Remediation. International Scholarly Research Notices, 2011, Article ID: 402647.

https://doi.org/10.5402/2011/402647

Zhang, X., Yang, L., Li, Y., Li, H., Wang, W., \& Ye, B. (2011). Impacts of Lead/Zinc Mining and Smelting on the Environment and Human Health in China. Environmental Monitoring and Assessment, 184, 2261-2273.

https://doi.org/10.1007/s10661-011-2115-6 